\title{
Reassessing China's Higher Education Development: A Focus on Academic Culture
}

\begin{abstract}
During the past three and a half decades, China has been progressing in higher education in a surprisingly dramatic manner, evidenced especially by scientific publications and sheer numbers of graduates. Such a fact has national, regional and global implications. China's higher education development and its future directions are now placed highly on the research agendas of many from various parts of the world. Unlike the general acknowledgement of China's achievements, assessment of the future development of China's higher education is wide open to question. To some, Chinese universities are on a trajectory to become "world-class" and China's high-flyers challenge Western supremacy. To others, China's notion of "world-class" status has been largely imitative. Pumping resources into universities will only lead to diminishing returns as Chinese culture and practices will act as a brake to the pursuit of academic excellence. An increasing deal of attention has been paid to where China will be located in a global higher education landscape and in what shape. Based on the author's longstanding professional observation and recent empirical studies, this article assesses China's higher education development, with a particular focus on the challenges brought forward by academic culture. It interrogates China's pride of the idea that Chinese universities are not willing to assume that Western models define excellence, and asks how far Chinese universities could move within their current development model.
\end{abstract}

\section{Introduction}

Since the late 1970s, China's higher education has made some impressive progress. Admission has expanded dramatically since 1999. China's higher education system has become the world's largest in terms of sheer numbers of teachers and students. By 2014, 35.59 million students enrolled in China's 2,529 regular and 295 adult higher education institutions, with a gross enrolment rate of $37.5 \%$. Annual postgraduate admissions reached 621,300, with 548,700 and 72,600 respectively at Master's and doctoral levels and a total of 1,847,700 at-school postgraduate students. Teaching and administrative staff members reached 2,335,700 with 1,534,500 full-time teachers and a student-teacher ratio of 17.68:1. There were 728 private higher education institutions, enrolling 408 Master's, 3,748,300 undergraduate and 2,122,800 associate degree students (Ministry of Education, 2015).

As for research, especially in science and engineering fields, China's progress has been formidable. China is now the world's third largest producer of peer-reviewed research articles after the European Union and United States. According to Science and Engineering Indicators 2014 published by the US National Science Foundation, out of the world's 827,705 articles published in 2011, researchers in the combined 28 European Union countries produced 254,482 articles (31\%), the United States 212,394 (26\%), China 89,894 (11\%) and Japan 47,106 (6\%). Chinese science is clearly on the rise. China is pushing hard to increase its share of global research and development (Kigotho, 2014). Its output has surged during the past decade. The number of papers authored by Chinese scientists grew an average of more than $15 \%$ annually during 2001-2011, rising from 3\% of global research article output to $11 \%$ over the decade (Morrison, 2014).

With a well-established modern Western-style higher education system, China's achievement appears even more remarkable when compared with other non-Western societies. While such achievements have been widely acknowledged, assessment of China's future development of higher education is not. To some, Chinese universities are leaping ahead to join 
the distinguished league of the world's leading universities (Morgan, 2011), challenge Western supremacy and gradually eclipse the Western university system (Healey, 2012). To others, they still lag far behind the best universities in the West (Mohrman, 2005). A kind of "glass ceiling" is to be reached soon (Altbach, 2010). While both views cite culture as the reason, neither of them shows sufficient understanding the Chinese culture. With its strong traditions in higher learning that are fundamentally different from the Western, China faces consistent tensions with the contemporary dominant Western university model. Integrating its cultural roots and heritages with Western higher education values has rarely been fulfilled (Yang, 2013).

China's achievement is a combined effect of many factors, including its strikingly different higher learning traditions, chequered history of transplanting foreign education patterns, already well established moden Western-styled higher education system, remarkable economic growth in recend decades, and its tremendous talent pool. The fact that the Chinese experience could possibily offer an alternative to Western models makes the experience interesting to observers. Higher education development is always resulted from the past, the contemporary, the local, and the global. Its reality includes success and failures, costs and benefits, as well as twists and turns. However, most existing studies are often confined to certain dimensions and aspects of such highly complex issues. Furthermore, although universities are cultural institutions and China is particularly rich in higher learning traditions, a cultural perspective is often lacking in assessing China's higher education development. This article attends to the historical and cultural roots of Chinese higher education, and focuses especially on academic culture.

Engaged closely with the general literature on this topic to shed light on China's higher education development, this article incorporates findings from ethnographic interviews conducted at Peking and Tsinghua Universities in 2014. A case study approach is used to gain an in-depth understanding of the complexities from within the individual institutions in their unique settings (Hargreaves, 1993). Semi-structured interviews were employed as the main method of data collection to access the 'lived experience' of participants (Marshall \& Rossman, 2006). The sampling was 'purposive' (Punch, 2009). The choice of the two institutions was based on the fact that they reflect the two major types of institutions within the sector: 'comprehensive' and 'technological' universities. Within each university, participants were drawn from both administrators and grassroots academics. Participants included eight from Peking University and eleven from Tsinghua University, with intended differentiation in rank, gender and disciplinary backgrounds. Many held academic and administrative leadership positions at that time, as shown by Tables 1 and 2 below: 
Table 1: Interviewees from Peking University

\begin{tabular}{|lllllll|}
\hline Interviewee & Gender & Age & PhD & Discipline & Professional Rank & $\begin{array}{l}\text { Administrative Level } \\
\text { BJ1 }\end{array}$ \\
\hline M & $50-60$ & Overseas & Science & Professor & Department Head \\
\hline BJ3 & M & $40-50$ & Domestic & Social Science & Professor & $\begin{array}{l}\text { Mid-level University } \\
\text { Administration }\end{array}$ \\
\hline BJ4 & M & $40-50$ & Domestic & Social Science & Professor & Faculty Dean \\
\hline BJ5 & M & $50-60$ & Overseas & Science & Professor & - \\
\hline BJ6 & M & $40-50$ & Domestic & Social Science & Associate Professor & $\begin{array}{l}\text { Mid-level University } \\
\text { Administration }\end{array}$ \\
\hline BJ7 & M & $40-50$ & Domestic & Social Science & Professor & $\begin{array}{l}\text { Mid-level University } \\
\text { Administration }\end{array}$ \\
\hline BJ8 & F & $50-60$ & Overseas & Science & Professor & $\begin{array}{l}\text { Mid-level University } \\
\text { Administration }\end{array}$ \\
\hline
\end{tabular}

Table 2: Interviewees from Tsinghua University

\begin{tabular}{|lllllll|}
\hline Interviewee & Gender & Age & PhD & Discipline & Professional Rank & $\begin{array}{l}\text { Administrative } \\
\text { Level }\end{array}$ \\
\hline QH1 & M & $60-70$ & Domestic & Engineering & Professor & $\begin{array}{l}\text { University-level } \\
\text { Administration }\end{array}$ \\
\hline QH2 & M & $50-60$ & Overseas & Science & Professor & - \\
\hline QH3 & M & $50-60$ & Domestic & Social Science & Professor & Faculty Dean \\
\hline QH4 & F & $50-60$ & Overseas & Human science & Professor & Department Head \\
\hline QH5 & F & $40-50$ & Domestic & Social Science & Associate Professor & Office Director \\
\hline QH6 & M & $60-70$ & Overseas & Engineering & Professor & Former University \\
& & & & & Leader \\
\hline QH7 & M & $50-60$ & Overseas & Engineering & Professor & Center Director \\
\hline QH8 & M & $60-70$ & Domestic & Social Science & Professor & Faculty Dean \\
\hline QH9 & F & $50-60$ & Overseas & Human Science & Professor & - \\
\hline QH10 & M & $50-60$ & Overseas & Engineering & Professor & Center Director \\
\hline QH11 & M & $50-60$ & Domestic & Engineering & Associate Professor & Mid-lev University \\
& & & & & & Administration \\
\hline
\end{tabular}

\section{China's Traditions in Higher Learning}

Higher education is deeply rooted in culture. Human civilizations of diverse regions of the world have had their various higher learning traditions. The most fundamental challenge for China's higher education is cultural. During its ancient civilization for thousands of years, China developed its rich traditions in higher learning that contrast sharply to those in the West. Ancient Chinese higher learning institutions appeared in the Western Zhou Dynasty (1046-771 BCE). The famous Jixia Academy was established before the Platonic Academy in Greece. Chinese ancient education focused on knowledge of human society, with its central focus on political utility defined by the ruling classes. Higher learning institutions were loyal servants of the emperor. The Imperial Examinations and the Academies (or Shuyuan) were key elements of ancient Chinese higher learning. 
The Chinese tradition was characterized by close integration within a meritocratic bureaucracy that entrusted governance to those who could demonstrate their knowledge through written examinations. Chinese classical higher learning featured a Confucian approach to scholarship, which put emphasis on connectedness and integration "between theory and practice, fact and value, individual and community, institution and political-social-natural context" (Hayhoe, 2001, p. 347). Chinese long higher learning tradition portrays unique China's way of thinking about human individuals, society and nature as well as the relations between them. Higher learning was to prepare would-be officials for the state. Higher institutions were a subsidiary body of the bureaucratic system. As part of the ruling system, they neither could nor attempted to go beyond the imperial framework. Even private ones set their eye only at the imperial examination in the hope of winning an official rank (Zhang, 2009).

Such a mode of thinking has had a strong impact on the development of China's higher education. Lacking an interest in seeking knowledge for its own sake, traditional Chinese higher education placed its central focus on utility, in the terms of the ruling classes. No institution in Chinese tradition could be called a university. Chinese institutions were highly reliant on their relations with the ruling elites (Hayhoe, 1996). The imperial examination system began to take form around 400 C.E. and reached its full institutional development in the Tang dynasty (618907 C.E.). During the Song (960-1279 C.E.), it crystallized into patterns that were to last right up to 1911 . The academies took their definitive forms in the Song dynasty, as what had been originally libraries or centers for scholarly discussion developed into academies that provided a structured learning environment separate from, yet interacting with, state institutions associated with the imperial examination system.

Some sinologists stress the private nature and freethinking atmosphere of the academies (Hayhoe, 1989). However, the academies did not always maintain those features. Their longstanding historical development bore a marked brand of ideological and financial control by the government. They focused initially on exploring Confucianism and personal intellectual cultivation than training government officials, with operating funds coming mainly from private sources. They became prosperous through winning recognition and financial support from the Song rulers. The government extended its control via donations of books and land. With gradual loss of independence from the government, the academies became a major part of the government education system, and trained many officials during the Southern Song dynasty (1127-1279). They were integrated into the government school system from the Yuan to the Qing dynasties. By the Qing dynasty (1644-1911), their major aim had turned to preparation for the imperial examination in the hope of winning an official rank (Zhang, 2009).

The Chinese tradition therefore contrasts markedly with medieval universities which were autonomous corporations of students and masters, governed by internal rules set by the academic community itself and protected from the outset by Pope Gregory IX's bull. They were self-financing, depending either on their properties or on contributions from students for their income. They were small, independent institutions catering to the elite and governed by their own members, who elected a rector (Mora, 2001). Compared with the European curriculum that was featured by a hierarchical structure of knowledge and a dualism in epistemology and value neutrality, traditional Chinese scholarship was more fluid and less absolute in the lines it drew to separate itself from the natural environment, the political system, and religious authority (Hayhoe, 2001).

What is now described as the "global research university" is rooted in the universities established in Europe during the Middle Ages. The model was profoundly shaped by $19^{\text {th }}$ century 
Germany and $20^{\text {th }}$ century America and spread around the world both through colonization and the emulation of its scientific achievements and contribution to nation building. China began to experiment with such universities in the late $19^{\text {th }}$ century, with its first modern institution established in 1895. Attempts to indigenize the Western idea of a university have since never stopped, with successes to varying degrees at different levels (Yang, 2013). Achievements were most evident at the individual level typified by Cai Yuanpei. Institutional success was exemplified by the National Southwestern Associated University during the Second SinoJapanese War. At the system level, the period of 1911-1927 saw real efforts to set up a "university" in the sense of the defining values of autonomy and academic freedom, due mainly to the lack of a strong central government (Hayhoe, 1996).

The markedly different cultural roots and heritages have led to continuous conflicts between the traditional Chinese and the imposed Western ideas of a university. Modern Chinese universities have their institutional establishments based on Western values on one hand and another system supported by traditional culture on the other. The two systems often do not support each other. Instead, constant tensions between them reduce the efficiency of university operation, and China's unique traditions have become a problem instead of an asset in the modernization of higher education. The two systems have never been on equal footing either. Even with the recent developments, the Western model influences the direction of change in Chinese institutions of higher education. Chinese universities now look to the most elite American counterparts for standards, policy innovation and solutions to their own development problems. The merging of Chinese and Western ideas of a university remains an unfinished business.

For China, the coexistence of two powerful systems based on strikingly different cultural values proves an extremely tough challenge. While the choice for having both at the same time appears to be the only reality for the Chinese, the two systems do not tolerate each other easily. Traditional ways of thinking have survived dramatic social and cultural changes in China's modern history, and remained deeply rooted among the Chinese people. Their impact on contemporary Chinese higher education is amazingly profound. The clash between the two traditions forms the most fundamental cultural condition for China's contemporary higher education development. It is a specter that has been lingering and haunting East Asia for more than a century. The "pain" it has caused could be felt constantly and regularly. While most East Asian societies share such a challenge, the extent varies depending on their differing social, political and historical situations. The question for China is: how far can Chinese higher education go under such a circumstance? Meanwhile, this makes China's case interesting to observe whether or not China could provide an alternative to the dominant Western models.

My empirical work shows that very few respondents who are usually outside the field of higher education could articulate the issue from a cultural perspective. However, when explained clearly to them, most of them agreed with the coexistence of two systems, and felt difficult to bring both into line in their daily work. Therefore few Chinese have been able to theorize how China's universities differ from their Western counterparts. This is hardly surprising considering the striking cultural differences at a fundamental level on the one hand and the dominant Western models on the other (Jaschik, 2011). It is fair to note the awareness of such a need and even a sense of urgency among some leaders of China's best universities. However, neither they nor higher education researchers have been able to come out with anything of real substance about how Chinese universities differ from or can be different from their Western counterparts, both conceptually and practically. They describe the differences rhetorically, often borrowing 
expressions and even slogans frequently found in China's official policy documents, such as Chinese cultural roots (BJ-6; BJ-7; QH-1), China's social and economic development (BJ-4; QH-2; QH-10), and institutional and/or systemic governance (BJ-3; BJ-6, QH-11).

Both the inability to theorize the differences between Chinese and Western universities and the awareness of the need for Chinese identity are familiar scenarios among East Asian societies. For instance, when Professor Tan Chorh Chuan, President of the National University of Singapore, was interviewed by the Korea Times in June 2014, he was reported to use the word "different" emphatically. "We don't have to follow the same patterns that are happening in the West. We should be learning. We should be leapfrogging. We should be doing different things and trying different models," he said (Jung, 2014). However he failed to delivered anything substantial that could be a solid basis for such intended differences. Such a response has been confirmed repeatedly by my research interviews with major scholars and university leaders throughout East Asia. For instance, Professor Hong Hocheng and Professor Yang Pan-Chyr, Presidents of the National Tsinghua University and the National Taiwan University respectively, stressed this most clearly in my recent interviews with them. ${ }^{1}$

However, all hope is not lost. Interestingly, when asked for differences between future Chinese and current Western world-class universities, one respondent, a mid-level administrator, stressed the similarities instead. According to him, the differences should be an accumulation of long-term incremental development and seriously striving for clear identity at an early stage might not be a "wise" strategy. He remarked:

It's a matter of time, but hard to say when. We need to wait and we are all hopeful. Once we reach certain level, we will have our own features accumulated for a long time of development. (BJ-2)

His confidence was echoed by two other respondents, for example:

A "glass ceiling" might exist. It might be 10 meters high. We are not there yet, perhaps only 2-3 meters high. Once we are there, we might find some cracks in it, or we can see whether it's thin or think. We might find ways to get through or avoid it. Our world-class universities will take some time to achieve, but we will get there. (BJ-6)

We need to do well by some hard indicators in order to be acknowledged internationally as world-class... Our future looks bright. We have built up our hardware. We will succeed. But it's not the time yet to claim a comprehensive win. (BJ-7)

\section{Academic Culture as a Global Issue}

Academic culture is central to successful institutions and to an effective higher education system. World-class universities require a vibrant, merit-based academic culture to guarantee certain conditions for academic work and ensure their high levels of productivity and performance (Altbach, 2011). Academic culture refers to the attitudes, beliefs and values held by academics in relation to all aspects of their work. A variety of highly related terms have also been used widely,

\footnotetext{
${ }^{1}$ The interviews with Professor Hong Hocheng and Professor Yang Pan-Chyr were respectively conducted on May 29 and June 1 in 2015 at their offices.
} 
such as "integrity", "ethics", “(mis)conducts" and even "corruption”. Higher education has its special standing in a society, and therefore a corrupt academic culture damages the standing of institutions and the academic community badly (Altbach, 2004a). According to the Collins English Dictionary (1994), academic culture refers to the attitudes, values and beliefs that exist in higher education institutions. Such a culture exists alongside the culture of the rest of the country. Academic culture includes among other things the rules and regulations for appropriate behavior on the part of members of a university, and the philosophy that underlies their work. It is also about the beliefs held by them, such as a belief in original research and critical thinking.

As a set of attitudes, beliefs, and values that integrates a specific group of academics (Maassen, 1996), academic culture has strong impact on what is done, how it is done, and who is involved in doing it, concerning decisions, actions, and communication on both instrumental and symbolic levels (Chaffee \& Tierney, 1988). Altbach (2004b) has consistently cited academic culture as a significant impediment for East Asian higher education to reach the leading status in the world. He uses terms including "academic life' (research, the distribution of research, the students, and the academic profession) (p. 14); "academic institutional traditions" (academic freedom, institutional autonomy, the relationship of the university to society) (p. 15); (indigenous) "intellectual and academic traditions", "academic model" and "the baggage of their historical past" (p. 18); and "shallow roots in the soil of their countries-the norms and values of academe" (p. 19). According to him, an academic culture that is based on meritocratic values, free inquiry, and competition is largely absent in East Asia (Altbach, 2010).

Recently, issues connected with academic culture have been fast growing worldwide. An increasing number of cases about academic misconducts are reported, with stories of academic corruption frequently appearing in the global news media (Macfarlane, Zhang \& Pun, 2014). Academic corruption is much more visible than decades ago (Pacheco, 2011). It endangers universities seriously with significant impact on the access, quality and equity in education (Hallak \& Poisson, 2002). The world has witnessed a dramatic increase in academic corruption (Altbach, 2005; Hallak \& Poisson, 2007). Academic misconduct can be found in both developed and developing countries, but is especially prevalent in nations whose higher education systems have little external supervision and inadequate quality assurance mechanisms. It is also particularly epidemic in countries where societal corruption is pervasive. It is multifaceted and complex because of the unique social, political, cultural and educational contexts where it occurs (Ren, 2012).

East Asia is no exception, although the actuality differs from country to country within the region. Throughout East Asia, academic dishonesty has always been a serious issue, from student cheating (Hu, 2014) to fraud by scientists (Strauss, 2014). Research shows increasing academic dishonesty in Hong Kong (Chapman \& Lupton, 2005; Mok, 2011) and Taiwan (Lin \& Wen, 2007). According to Song Jung-a (2014), South Koreans dub their nation the 'Republic of Plagiarism', where a former Olympic taekwondo champion and priest - alongside scores of academics and politicians - have all fallen on their swords after copying chunks of academic research. Perhaps more successfully than any other people of the world, the Japanese have evolved a social system capable of ensuring order and good behavior. However, Japan is by no means immune from academic fraud. For example, the 2000s witnessed a wide attention to highprofile cases of scientific misconduct (Slingsby, Kodama \& Akabayashi, 2006). More recently, Japanese academic establishment was stunned by Haruko Obokata's fabricating data, doctoring images, and plagiarism (McNeill, 2014). Scholars have thus paid attention to the impact of academic culture on national higher education development (Shin, 2009). 


\section{Academic Culture in Chinese Higher Education}

China faces serious challenges of academic culture, with widespread academic cronyism (Xiao, 2014). Since the 1990s, academic culture has fast become decadent and penetrated deeply into the higher education sector from regional to national flagship institutions in almost every aspect of university operation. The problem has taken various forms including falsifying and plagiarizing academic achievements of others, obtaining scientific research projects or rewards by bribery and other illegal means, deliberately hiding academic scandal and covering up academic corruption by universities or research institutions. Those involved include students, professors, institutional leaders, and academicians (Yang, 2005). The flowing quotes indicate the width and depth of the issue:

Today we are so difficult to be pleased (materially). We spend so much time and energy on moonlighting with little time left for real academic work and even less for students. (BJ-2)

Our colleagues compete hard for benefits, not for productivity, even less for contribution. (QH-3)

Too many people in this university are keen to earn extra income outside. I've heard some of my colleagues saying openly that they only spend $1 / 10$ of their time and energy on their work of this university. (QH-4)

Look at our environment, what fills your eyes is widespread corruption and seemingly endless desire for instant benefits. This seriously affects our academic development. (BJ-8)

Our professors do not read. They look for things that are quick, easy and financial. The more famous they are the less real work they do. They are public relations people seeking opportunities (funding sources). This is the way things are done here. (BJ-6)

As a respondent at Peking University (BJ-3) explained, China's academic culture portrays the wider society. Within the system, performing research and holding an official capacity are closely linked. Academic performance has a direct bearing on advancement into administrative positions. Being promoted into government or even staying within universities with administrative positions can mean far more substantial financial reward than what pure academic work can bring in. Chinese scholars are therefore more and more prone to becoming trapped into the pursuit of administrative standing, rather than devoting their time to legitimate academic research, as described by a respondent who is an academician of Chinese Academy of Sciences:

These days, who wants to do the dirty work? Everyone wants to be an official. Some of my highly achieving doctoral graduates prefer to be administrators rather than academics simply for more resources. (QH-6) 
Under the influence of a corrupt academic culture, guanxi restricts free movement of staff, students and resources and career advancement of faculty. Decision-making is not based on academic merit, but personal relationships and preferential treatment. Plagiarism and the falsification of scientific results are common. Those in powerful positions carve up major research grants. Without many opportunities left for diligent individuals, academics seek instant success and quick profits only, and their misconducts could be easily found in daily academic and administrative affairs. The toxic culture has devastating effects on higher education development and the entire nation's modernization, leading to distortion and inefficiency of institutions and the system. It causes great damage to individual and institutional morale and to the style of academic work nationally, ruins the academic atmosphere of Chinese universities and pollutes the mind of young students. It is serious enough to keep the development of China's advanced science from success (Guo, 2010).

The situations are similar even at Peking and Tsinghua Universities which are China's most prestigious higher education institutions with long-held strong academic atmosphere. Tsinghua University's people are particularly well-known for being work-efficient and job-solid. Among the respondents from the two institutions, however, including those who are highly positive about their universities, all acknowledged the serious issue of academic culture, as illustrated by a renowned scientist at Tsinghua University:

Academic culture is indeed a major serious challenge for building China's innovation system. It's almost everywhere at this institution. It indeed hinders development. (QH-7)

Compared with the fundamental cultural conflicts between Chinese and Western higher learning traditions, a rotten academic culture hurts the Chinese system more directly with evident impact on its everyday operations. It is far beyond the higher education sector to solve these widelyspread and deeply-rooted social problems. With rampant academic dishonesty, it is fair to point out that China's state education policies began to stress the need for preventing research misconduct in the early 1990s. In 2006, the Ministry of Science and Technology and the Ministry of Education stepped up efforts in building academic norms and research integrity, through developing standards and regulations, setting up special agencies, issuing policy papers, organizing national forums or seminars, and promoting international cooperation. Some universities have launched their specific units to deal with academic fraud and corruption (Sun, 2010). There are signs of clear awareness of such a serious issue within the Chinese higher education sector (Gong \& Liu, 2013). It is also reasonable to expect some positive instantaneous policy effects. Yet, considering the general shortage of social trust and the width and depth of the issue within the society, it is just not realistic to hope that the problem would be uprooted in the years to come. This was confirmed repeatedly by the overwhelming majority of my respondents.

\section{Concluding Points}

Chinese universities have made tremendous strides in recent decades. Since the 1990s, China's higher education policies have aimed at both qualitative and quantitative developments, including the Program for Education Reform and Development in China (1993), the Education Act of the People's Republic of China (1995), the 211 Project (initiated in 1995) and the 985 Project (initiated in 1998), and the dramatic expansion starting from 1999. More recent is the quest for world-class universities. At certain stage, China's strategies have been effective. 
According to the latest Academic Ranking of World Universities (2015), China has 4, 3, 6, 14 and 5 in the top 101-150, 151-200, 201-300, 301-400 and 401-500 respectively, featuring 32 times in the top 500. With such success, there has been an evident pride of the idea that Chinese universities are not willing to assume that Western models define excellence, that is, the notion of the Chinese idea of the university (Yang, 2010). Debates have started over whether or not there might be an emerging Chinese model of the university (Zha, 2011; Li, 2012; Postilione, 2015).

However, the notion, which aims at a judicious combination of Chinese and Western traditions as the fundamental mission of China's universities, has never been materialized (Yang, 2013). Instead, China's promise is doomed to be limited (Altbach, 2010). Chinese universities still lag far behind the best in the West. They have been able to improve their hardware considerably, while the software building takes much longer. Financial and other resources combined with some innovation strategies can make progress only so far. Simply buying stateof-the-art laboratory equipment will not guarantee the kind of intellectual atmosphere that has developed over centuries on European and American campuses. It is remarkable to see how China's strong traditions in higher learning have survived dramatic social and cultural changes in China's modern history, and remained deeply rooted among the Chinese people. Their impact on current higher education development is profound. However, they have been a negative asset so far. Only when their function is turned to be positive, can Chinese higher education lead in the world and only by then can talks about Chinese model make real sense.

During my research fieldwork at China's top universities in Beijing in 2014, all the respondents expressed their optimism about China's success in world-class university bid (some were more cautious than others), despite that they differed substantially in their attitudes toward China's current situation especially in terms of academic culture. Even those who strongly criticized China's academic culture were still optimistic about China's success in creating worldclass universities. This contrasts sharply to the two extremes expressed in the English literature by international (usually Anglo-Saxon) observers. It begs a question about the interaction between recognition and perspective and the difficulty of knowing anything in its entirety. Being able to watch the development of their institutions from within and based on their actual experience give much weight to the judgment of the respondents. It also urges us to reflect on the influence of 'Western' anxieties on perceptions of the changing geopolitical architecture of higher education located within an East-West binary which imagines Asia to be the West's 'other' (Bhabha, 1994).

The bubbling and gurgling about China's rise in higher education in the English literature as well as in the media lacks a solid base. In the present great leap forward in Chinese higher education, what is often missing is sufficient attention to cultural and institutional establishments. Essentially, China's present higher education endeavor is part of its much more general process of seeking an alternative to Western globalization. Although integrating indigenous and Western ideas of the university is a must for the Chinese higher education system, it has never been achieved. Instead, the aforementioned two levels of challenges deal China's higher education weighty blows. Judged by the current practice and in consideration of China's deeply entrenched academic practices, China is likely to continue its path: learning the useful part while leaving the ideological aside. A handful of China's flagships will join the distinguished leagues of the world's leading universities in scientific and technological research without much social and cultural influence at a global level. This does not mean Chinese universities challenge Western supremacy, especially because university development is not a zero-sum game. 


\section{References}

Academic Ranking of World Universities (ARWU), Shanghai Jiao Tong University (2015). Academic ranking of world universities. Retrieved from http://www.shanghairanking.com/World-University-Rankings-2015/China.html

Altbach, P. G. (2004a). The question of corruption in academe. International Higher Education 34: 8-10.

Altbach, P. G. (2004b). The past and future of Asian universities: Twenty-first century challenges. In P. Altbach \& T. Umakoshi (Eds.), Asian universities: Historical perspectives and contemporary challenges (pp. 13-32). Baltimore: The Johns Hopkins University Press.

Altbach, P. G. (2005) Academic corruption: The continuing challenge. International Higher Education 38: 5-6.

Altbach, P. G. (2010) 'The Asian higher education century?', International Higher Education, 59: 3-5.

Altbach , P. G. (2011). BRIC realities: The need for academic culture. Retrieved from https://www.insidehighered.com/blogs/world-view/bric-realities-need-academic-culture-0

Bhabha, H. (1994). The location of culture. London: Routledge.

Chaffee, E. E., \& Tierney, W. G. (1988). Collegiate culture and leadership strategies. New York: American Council on Education and Macmillan.

Chapman, K. \& Lupton, R. (2004). Academic dishonesty in a global educational market: a comparison of Hong Kong and American university business students. The International Journal of Educational Management, 18, 425-435.

Collins English Dictionary (1994). Glasgow: HarperCollins.

Gong, L. Y. \& Liu, J. W. (2013). On academic culture and university soft power. Academic Exchange 6: 216-219. (In Chinese)

Guo, J. X. (2010). Academic corruption undermining higher education: Yau Shing-tung. China Daily, June 2. Retrieved from http://www.chinadaily.com.cn/hkedition/201006/02/content_9919871.htm

Hallak, J. \& Poisson, M. 2002. Ethics and corruption in education (Policy Forum No. 15). Results from the Expert Workshop held at the IIEP, 28-29 November, 2001. Paris: IIEPUNESCO.

Hallak, J. \& Poisson, M. (2007). Corrupt schools, corrupt universities: What can be done? Paris: International Institute for Educational Planning.

Hargreaves, D. (1993). What happened to symbolic interactionism? In M. Hammersley (Ed.), Controversies in classroom research (pp. 135-152). Buckingham: Open University Press.

Hayhoe, R. (1989). China's universities and Western academic models. Higher Education, 18(1), 49-85.

Hayhoe, R. (1996). China's universities 1895-1995: A century of cultural conflicts. New York and London: Garland Publishing, Inc.

Hayhoe, R. (2001). Lesson from the Chinese academy. In R. Hayhoe \& J. Pan (Eds.), Knowledge across cultures: A contribution to dialogue among civilizations (pp. 323-347). Hong Kong: Comparative Education Research Centre, The University of Hong Kong.

Healey, N. (2012). Asia: The new powerhouse? ACA (Academic Cooperation Association) European Policy Seminar: Higher Education in 2030. Brussels, 12 October. 
Hu, J. C. (2014, August 6). Why do scientists commit fraud? Science. Retrieved from http://www.slate.com/articles/health_and_science/science/2014/08/fraud_in_stem_cell_resea rch_japanese_biologist_yoshiki_sasai_commits_suicide.html

Jaschik, S. (2011) 'How Asian are Asian universities?' Inside Higher Ed, March 14. Retrieved from http://www.insidehighered.com/news/2011/03/14/asian_university_leaders_consider_identity _of_their_institutions

Jung, M. (2014). Bright future for Asian universities. The Korea Times, June 18. Retrieved from http://www.koreatimes.co.kr/www/news/nation/2015/01/181_159335.html

Kigotho, W. (2014). China's rapid rise in global science and engineering. World University News 28 February 2014 Issue No: 309. Retrieved from http://www.universityworldnews.com/article.php?story=20140227152409830

$\mathrm{Li}$, J. (2012). World-class higher education and the emerging Chinese model of the university. Prospect, 42 (3), 319-339.

Lin C. H. S., \& Wen, L. Y. M. (2007). Academic dishonesty in higher education: A nationwide study in Taiwan. Higher Education, 54, 85-97.

Maassen, P. (1996). The concept of culture and higher education. Tertiary Education and Management 1(2), 153-159.

Macfarlane, B. Zhang, J.J. \& Pun, A. (2014). Academic integrity: A review of the literature, Studies in Higher Education, 39(2), 339-358.

Marshall, C., \&Rossman, G. (2006). Designing qualitative research. Thousand Oaks, CA: Sage.

McNeill, D. (2014, July 6). Academic scandal shakes Japan. The Chronicle of Higher Education. Retrieved from http://www.nytimes.com/2014/07/07/world/asia/academic-scandal-shakesjapan.html?_r=0

Ministry of Education (2015). National education statistics bulletin in 2014. Retrieved from http://www.moe.gov.cn/jyb_xwfb/gzdt_gzdt/s5987/201507/t20150730_196698.html

Mohrman, K. (2005). Sino-American educational exchange and the drive to create world-class universities. In C. Li (Ed.), Bridging minds across the Pacific (pp. 219-235). Lanham: Lexington Books.

Mok, D. (2011, June 29). Academic accused of misconduct. South China Morning Post. Retrieved from http://www.scmp.com/article/972057/academic-accused-misconduct

Mora, J. G. (2001). Governance and management in the New University. Tertiary Education and Management, 7, 95-110.

Morgan, J. (2011) 'Sun sets on western dominance as East Asian Confucian model takes lead,' Times Higher Education, 24 February.

Morrison, J. (2014, February 6). China becomes world's third-largest producer of research articles. Nature. Retrieved from http://www.nature.com/news/china-becomes-world-s-thirdlargest-producer-of-research-articles-1.14684

Pacheco, I. (2011). Is academic corruption on the rise? Inside Higher Ed. Retrieved from https://www.insidehighered.com/blogs/the_world_view/is_academic_corruption_on_the_rise

Postiglione, G. (201). Research universities for national rejuvenation and global influence: China's search for a balanced model. Higher Education. Published online 10 December 2014. DOI 10.1007/s10734-014-9838-6

Punch, K. (2009). Introduction to research methods in education. London: Sage

Ren, K. (2012). Fighting against academic corruption: A critique of recent policy developments in China. Higher Education Policy 25: 19-38. 
Shin, J. C. (2009). Building world-class research university: Brain Korea 21 project. Higher Education 58: 669-688.

Slingsby, B. T., Kodama, S. \& Akabayashi, A. (2006). Scientific misconduct in Japan: The present paucity of oversight policy. Cambridge Quarterly of Healthcare Ethics 15: 294-297.

Song, J-a (2014, September 11). Plague of plagiarism tarnishes South Korea's credibility, Final Times. Retrieved from http://www.ft.com/intl/cms/s/0/28387268-26bd-11e4-bc1900144feabdc0.html\#axzz3GYrd2AC7

Strauss, V. (2014, December 8). For third straight month, cheating alleged on SAT given in Asia. The Washington Post. Retrieved from http://www.huffingtonpost.com/2014/12/01/satcheating-china-korea_n_6228056.html

Sun, P. (2010). China's efforts for promoting research integrity. Professional Ethics Report 13, no. 4: 1-3.

Xiao, H. W. (2014). Chinese universities: beware cronyism. Nature, 515, 492.

Yang, R. (2005). Corruption in China's higher education system: A malignant tumor. International Higher Education 39: 18-20.

Yang, R. (2010) Much cry but little wool: Peking University personnel reforms. International Higher Education, 60, 10-11.

Yang, R. (2013). Indigenizing the Western concept of the university: Chinese experience. Asia Pacific Education Review, 14(1), 85-92.

Zha, Q. (2011). Is there an emerging Chinese model of the university? In R. Hayhoe, J. Li, J. Lin \& Q. Zha (Eds.), Portraits of 21 st century Chinese universities: In the move to mass higher education (pp. 451-471). Hong Kong: Comparative Education Research Centre, The University of Hong Kong \& Dordrecht: Springer.

Zhang, Y. (2009). Western ideas of a university in China: Introduction and impact. Hangzhou: Zhejiang University Press. (In Chinese) 